\title{
Noroviruses associated with acute gastroenteritis in a children's day care facility in Rio de Janeiro, Brazil
}

C.I. Gallimore ${ }^{1}$, M.A.B. Barreiros ${ }^{2,4}$, D.W.G. Brown ${ }^{1}$, J.P. Nascimento ${ }^{3}$ and J.P.G. Leite ${ }^{4}$

\section{Correspondence}

J.P.G. Leite

Laboratório de Virologia Comparada DV, IOC, Fiocruz

Avenida Brasil, 4365

Pav. Cardoso Fontes

21045-900 Rio de Janeiro, RJ

Brasil

Fax: +55-21-2598-4215

E-mail: jpgleite@ioc.fiocruz.br

Research supported in part by the British Council/Fiocruz exchange program for C.I. Gallimore and M.A.B. Barreiros, CNPq, and FAPERJ.

Received September 22, 2003 Accepted January 5, 2004

\begin{abstract}
Noroviruses (Norwalk-like viruses) are an important cause of gastroenteritis worldwide. They are the most common cause of outbreaks of gastroenteritis in the adult population and occur in nursing homes for the elderly, geriatric wards, medical wards, and in hotel and restaurant settings. Food-borne outbreaks have also occurred following consumption of contaminated oysters. This study describes the application of a reverse transcription-polymerase chain reaction (RT-PCR) assay using random primers (PdN6) and specific Ni and E3 primers, directed at a small region of the RNA-dependent RNA polymerasecoding region of the norovirus genome, and DNA sequencing for the detection and preliminary characterisation of noroviruses in outbreaks of gastroenteritis in children in Brazil. The outbreak samples were collected from children $<5$ years of age at the Bertha Lutz children's day care facility at Oswaldo Cruz Foundation (Fiocruz), Rio de Janeiro, that occurred between 1996 and 1998, where no pathogen had been identified. At the Bertha Lutz day care center facility, only Fiocruz's employee children are provided for, and they come from different social, economic and cultural backgrounds. Three distinct genogroup II strains were detected in three outbreaks in 1997/98 and were most closely related to genotypes GII-3 (Mexico virus) and GII4 (Grimsby virus), both of which have been detected in paediatric and adult outbreaks of gastroenteritis worldwide.
\end{abstract}

\section{Introduction}

The Norwalk-like viruses have recently been reclassified as noroviruses $(1,2)$ by the International Committee on the Taxonomy of Viruses. They are also known as small round structured viruses (3), a name based on their morphological appearance as seen by electron microscopy. Norovirus (Norwalklike virus) is a genus in the family Caliciviri-
Key words

- Noroviruses

- Day care center

- Gastroenteritis

- Genotypes dae along with the other human calicivirus genus Sapovirus (Sapporo-like virus). The Lagovirus (rabbit haemorrhagic disease virus) and the Vesivirus (vesicular exanthema of swine virus) complete the Caliciviridae. The prototype strain of noroviruses is Norwalk virus, a genogroup I strain. The genomic diversity of noroviruses includes two genogroups (I and II) $(4,5)$ and a number of genotypes, which have yet to be formally 
agreed upon. The genogroup I strains include GI-1 (Norwalk virus), GI-2 (Southampton virus), GI-3 (Desert Shield virus), and GI-4 (Valetta virus) (6) and the genogroup II strains include GII-1 (Hawaii virus), GII-2 (Melksham virus), GII-3 (Mexico virus), and GII-4 (Grimsby virus) (6). However, genogroup II strains are the predominant strains responsible for outbreaks of gastroenteritis worldwide, including the United States of America $(5,7)$, Germany (8), the Netherlands $(9,10)$, United Kingdom (11$14)$, and South Africa $(15,16)$.

Only a few studies have investigated the molecular and sero-epidemiology of noroviruses in South America. The genomic diversity of noroviruses in children in a Brazilian shantytown was investigated by Parks et al. (17). Sero-prevalence and sero-incidence studies for norovirus have shown a $71 \%$ rate in Brazilian children (18); 39 to $100 \%$ of Amazonian Indians were found to have antibodies to Norwalk virus (19) and 67 to $91 \%$ of Chilean adults and children had antibodies to Mexico and Norwalk virus $(20,21)$. Norovirus studies of the paediatric population have been undertaken in various countries including Argentina (22), Japan (23-25), South Africa (26), Canada (27), Mexico $(28,29)$, Spain (30), France (31), Germany (32), and Finland $(33,34)$.

This study describes the application of a broadly reactive norovirus reverse transcription-polymerase chain reaction (RT-PCR) assay to investigate several large outbreaks of acute non-bacterial gastroenteritis in a children's day care facility in Rio de Janeiro, Brazil, from 1996 to 1998.

\section{Material and Methods}

\section{Children's day care facility}

Between April 1996 and March 1998, eight outbreaks of acute gastroenteritis occurred at the Bertha Lutz day care facility at the Oswaldo Cruz Foundation, Rio de Janeiro,
Brazil. In four of eight outbreaks (April 1996, May and September 1997, and March 1998) no etiological agent had been identified. At the Bertha Lutz day care center facility, only Fiocruz's employee children are provided for, and they come from different social, economic and cultural backgrounds. A total of 132 fecal samples from children up to 5 years of age were obtained from these four outbreaks: 23 fecal samples in April 1996, 26 in May 1997, 71 in September 1997, and 12 from March 1998. All samples were stored as fecal suspensions at $-20^{\circ} \mathrm{C}$ and the study was undertaken between September and December 1999. Specific details on the outbreaks were not available.

\section{Nucleic acid extraction and RT-PCR assay}

Ten percent (weight/volume) fecal suspensions were prepared in $10 \mathrm{mM}$ Tris- $\mathrm{HCl}$ $\mathrm{Ca}^{2+}, \mathrm{pH} 7.2$, and stool suspensions were concomitantly used for ssRNA extraction by the glass powder method as described by Boom et al. (35). Complementary DNA (cDNA) was prepared by adding $40 \mu 1$ RNA (36) to $1 \mu 150 \mu \mathrm{M}$ random primers (PdN6, Amersham Biosciences, Chalfont St. Giles, Buckinghamshire, UK), followed by incubation at $70^{\circ} \mathrm{C}$ for $5 \mathrm{~min}$ and cooling on ice for $5 \mathrm{~min}$. This was followed by the addition of $13.5 \mu \mathrm{l}$ of a reverse transcription mix containing a final concentration of $10 \mathrm{mM}$ Tris, $\mathrm{pH}$ 8.0, $50 \mathrm{mM} \mathrm{HCl}, 5 \mathrm{mM} \mathrm{MgCl} 2,1$ $\mathrm{mM}$ of each dNTP (Amersham Biosciences), and 150 units of MuMLV-reverse transcriptase (Invitrogen, Paisley, UK) in a final volume of $54.5 \mu \mathrm{l}$. Reverse transcription was performed at $37^{\circ} \mathrm{C}$ for $1 \mathrm{~h}$. The reaction was stopped by incubation at $95^{\circ} \mathrm{C}$ for $5 \mathrm{~min}$ and then cooled on ice. cDNA $(5 \mu \mathrm{l})$ was added to a $45 \mu 1$ PCR mix containing a final concentration of $10 \mathrm{mM}$ Tris, $\mathrm{pH} 8.0,50 \mathrm{mM}$ $\mathrm{HCl}, 1.5 \mathrm{mM} \mathrm{MgCl} 2,1 \mathrm{mM}$ of each dNTP (Invitrogen), 20 pmol of each primer Ni and E3 (36) located in the RNA-dependent RNA polymerase-coding region, and 1 unit of TAQ 
DNA polymerase (Invitrogen). Products were amplified using the following conditions: $95^{\circ} \mathrm{C}$ for $2 \mathrm{~min}$ and 31 cycles of $95^{\circ} \mathrm{C}$ for 15 $\mathrm{s}, 40^{\circ} \mathrm{C}$ for $45 \mathrm{~s}$ and $72^{\circ} \mathrm{C}$ for $1 \mathrm{~min}$, followed by 1 cycle of $72^{\circ} \mathrm{C}$ for $5 \mathrm{~min}$ and holding at $15^{\circ} \mathrm{C}(36)$. The amplicons were then electrophoresed on $2 \%$ agarose gel in Tris-borateEDTA buffer in Wide Mini-Sub Cell GT (BioRad Laboratories, Hemel Hempstead, UK). The gel was stained with ethidium bromide $(0.5 \mu \mathrm{g} / \mathrm{ml})$ and PCR amplicons were visualized and photographed using a Gel Doc 1000 Polaroid system (BioRad). The Ni and E3 primers used in this study predominantly amplify GII strains, but will also amplify GI strains.

\section{PCR amplicon cloning and sequencing}

PCR amplicons for norovirus generated from fecal samples were cloned using a TA cloning system ${ }^{\circledR}$ (TOPO ${ }^{\circledR}$; Invitrogen). Two microliters of unpurified PCR amplicons was ligated to a $\mathrm{pCR}^{\circledR} 2 \cdot 1-\mathrm{TOPO}^{\circledR}$ vector, the ligation mix was incubated at room temperature for $5 \mathrm{~min}$ and a $2-\mu \mathrm{l}$ amount was added to the $50-\mu 1$ TOPO10' competent cells (Invitrogen) and incubated on ice for $30 \mathrm{~min}$. The cells were then heat shocked at $42^{\circ} \mathrm{C}$ for $30 \mathrm{~s}$ and immediately transferred to ice. Each transformation was incubated with $250 \mu$ of SOC medium (Invitrogen) at $37^{\circ} \mathrm{C}$ for 30 min in a shaking incubator. One hundred microliters of each transformation was spread on an L-agar plate containing ampicillin and X-gal/IPTG (Invitrogen) for blue/white colony selection and incubated at $37^{\circ} \mathrm{C}$ overnight.

Three white colonies from each transformation were sub-cultured onto an L-agar plate and incubated at $37^{\circ} \mathrm{C}$ overnight. The template for PCR was $1 \mu 1$ of a $100-\mu 1$ water/ colony heat denaturation preparation. The colonies were screened with $\mathrm{pCR}^{\circledR} 2.1$ $\mathrm{TOPO}^{\circledR}$ vector primers (PTAG5' primer 5' GCT ATG ACC ATG ATT ACG CCA A 3', downstream of an M13 reverse primer and
PTAG3' primer 5' TGT AAA ACG ACG GCC AGT GAA 3', which overlaps with the M13 (-20) forward primer) using the Expand High Fidelity PCR System ${ }^{\mathrm{TM}}$ (Roche Molecular Biochemicals, Lewes, UK). PCR amplicons were purified for sequencing PCR using a Geneclean ${ }^{\circledR}$ Spin kit (Anachem, Luton, UK). Purified DNA was sequenced in both directions using PTAG5' and PTAG3' primers, the Beckman Coulter ${ }^{\mathrm{TM}}$ CEQ2000 Dye Terminator Cycle Sequencing Quick Start kit (High Wycombe, UK), according to manufacturer instructions, and a Beckman CoulterTM CEQ2000 capillary sequencer. Generation of contiguous sequences and pairwise alignments of the 76-bp inter-primer region $(\mathrm{Ni} / \mathrm{E} 3)$ of the norovirus ORF1 sequences was performed using Genebuilder and Clustal in Bionumerics version 2.5 (Applied Maths, Kortrij, Belgium).

\section{Results and Discussion}

Noroviruses were detected in three of the four day care facility outbreaks examined for which no etiological agent had been identified. In outbreaks two (May 1997), three (September 1997), and four (March 1998), noroviruses were detected in $6 / 26(23 \%)$, $27 / 71(38 \%)$ and 8/12 (67\%) samples, respectively. Noroviruses were not detected in samples collected from outbreak 1 (April 1996).

The analysis of PCR amplicons by partial DNA sequencing confirmed that all norovirus strains belonged to genogroup II and the nucleotide alignments of the strains designated Bertha Lutz (BL) day care facility strains (BL2, BL3, and BL4) were compared with other reference strains from GenBank and the Enteric Virus Unit, norovirus sequence database at SRMD, London, UK (Figure 1). The BL2 strains from outbreak 2 in May 1997 had 100\% identity with Grimsby/ 1995/UK (Lordsdale/1995/UK-Genbank X86557), the BL3 strains from outbreak 3 in September 1997 had 90\% identity with Mur1/ 
Figure 1. Comparison of norovirus strains detected in a children's day care facility in Rio de Janeiro, Brazil, with strains described in other parts of the world. BL2-1 and 2-2 are strains from patients in outbreak 2 in 1997, BL3-1 to 3-4 are strains from patients in outbreak 3 in 1997, and BL4-1 to 4-3 are strains from patients in outbreak 4 in 1998. Genbank strains are Hawaii/1972/US (U07611), Melksham/1995/UK (X81879), Mur1/ 1997/JP (AB01929) Lordsdale/ 1995/UK (X86557), Mexico/ 1989/MX (U22498), Florida/ 1993/US (AF414407), and Saitama U25 (AB039780). For Grimsby/1995/UK, Hillingdon/ 1993/UK and Leeds/1990/UK, see Vinje et al. (4). Sequences of strains from this study are available from the author of correspondence.
1997/JP (AB01929), and the BL4 strains from outbreak 4 in March 1998 had 95\% identity with Mexico/1989/MX (Genbank U22498). The multiple strains from each outbreak demonstrated in Figure 1 were the only samples sequenced and all strains within an outbreak were identical.

This is the first report of noroviruses associated with outbreaks of gastroenteritis in day care facilities in Brazil. Further studies are needed to determine the extent of norovirus infection in outbreaks of foodrelated gastroenteritis and outbreaks in the paediatric and adult population in Brazil.

The low level of norovirus positivity in each outbreak was probably a result of the specimens being stored as fecal suspensions at $-20^{\circ} \mathrm{C}$ and examined $1-2$ years after collection.

Small regions of the polymerase gene were used for analysis, as the primers used had to be broadly reactive in order to amplify the cDNA of a wide range of genogroup II norovirus strain types, and although sequence data generated from a small region of the RNA polymerase should be interpreted with caution, previous phylogenetic studies using related primers have revealed a robust relationship between this small region amplified and more extensive regions of the polymerase gene (11-13).

The norovirus strain in outbreak 2 (BL2/ 1997/BR) in May 1997 was identical to Grimsby/1995/UK (4), a genotype GII-4 (Bristol/1993/UK) which is the commonest circulating strain in the UK and Europe. GII4 has been an endemic strain and the predominant strain in the UK since 1992, and has been responsible for 50 to $70 \%$ of norovirus outbreaks in each year except 1993/ 94 (14). The second outbreak of norovirus gastroenteritis which occurred in September 1997, was caused by a possible GII-4 (Bristol/ 1993/UK) variant strain (BL3/1997/BR) and is closely related to Mur1/1997/JP. The third norovirus outbreak was in March 1998 and

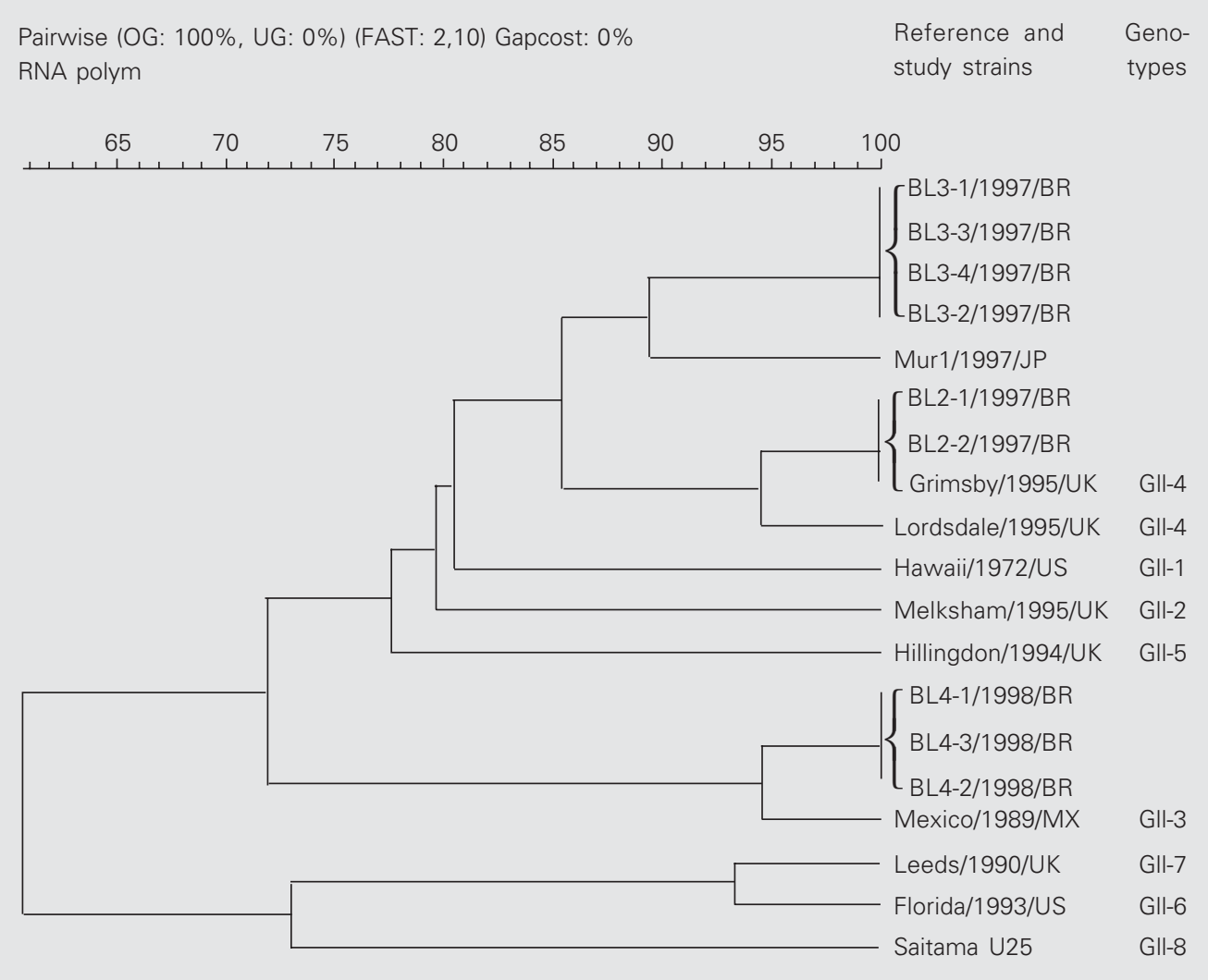


was caused by a GII-3-like (Mexico/1989/ MX) strain (BL4/1998/BR). The Mexico/ 1989/MX strain was responsible for an epidemic of norovirus gastroenteritis in 1993/ 94 in the UK (14), but has not been seen recently in the UK. No capsid data were available for the confirmatory genotyping of these Brazilian strains.

The importance of noroviruses infection in children has been well demonstrated in developed countries; however, little is known about the role of those viruses in sporadic cases or outbreaks of paediatric gastroenteritis in developing countries in South and Central America, Africa and Asia $(22,26,28)$. The strains mostly observed in Brazil and worldwide belong to genogroup II, previously in the North-East region of Brazil (17) and now in the South-East region in this study, as well as in other developing and developed countries (22-25,31-33). There is a need to examine the diversity of norovirus strains in populations in developing and developed countries for which data are not available, to better understand the virus epidemiology and its global spread.

The present study demonstrates that noroviruses are present in the paediatric population in Brazil. Further studies are needed to investigate the burden of gastroenteric illness due to noroviruses in the paediatric and adult population in Brazil.

\section{References}

1. Green KY, Ando T, Balayan MS et al. (2000). Taxonomy of the caliciviruses. Journal of Infectious Diseases, 181: S322-S330.

2. Mayo MA (2002). A summary of taxonomic changes recently approved by ICTV. Archives of Virology, 147: 1655-1663.

3. Caul EO \& Appleton H (1982). The electron microscopical and physical characteristics of small round structured fecal viruses: An interim scheme for classification. Journal of Medical Virology, 9: 257-265

4. Vinje J, Green J, Lewis DC, Gallimore Cl, Brown DW \& Koopmans MP (2000). Genetic polymorphism across regions of the three open reading frames of "Norwalk-like viruses". Archives of Virology, 145: 223-241.

5. Fankhauser RL, Monroe SS, Noel JS, Humphrey CD, Bresee JS, Parashar UD, Ando T \& Glass RI (2002). Epidemiologic and molecular trends of "Norwalk-like Viruses" associated with outbreaks of gastroenteritis in the United States. Journal of Infectious Diseases, 186: 1-7.

6. Green K, Chanock R \& Kapikian A (2001). Human caliciviruses. In: Knipe DM \& Howeley MM (Editors), Fields Virology. 4th edn. Lippincott Williams and Wilkins, Philadelphia, PA, USA, 841-874.

7. Fankhauser RL, Noel JS, Monroe SS, Ando T \& Glass RI (1998). Molecular epidemiology of "Norwalk-like viruses" in outbreaks of gastroenteritis in the United States. Journal of Infectious Diseases, 178: 1571-1578

8. Schreier E, Doring F \& Kunkel U (2000). Molecular epidemiology of outbreaks of gastroenteritis associated with small round structured viruses in Germany in 1997/98. Archives of Virology, 145: 443-453.

9. Vinje J \& Koopmans MP (1996). Molecular detection and epidemiology of small round-structured viruses in outbreaks of gastroenteritis in the Netherlands. Journal of Infectious Diseases, 174: 610-615.

10. Vinje J, Altena A \& Koopmans MPG (1998). The incidence and genetic variability of small round structured viruses in outbreaks of gastroenteritis in the Netherlands. Journal of Infectious Diseases, 176: $1374-1378$
11. Green J, Norcott JP, Lewis D, Arnold C \& Brown DWG (1993). Norwalk-like viruses: detection of genomic diversity by polymerase chain reaction. Journal of Clinical Microbiology, 31: 3007-3012.

12. Maguire AJ, Green J, Brown DWG, Desselberger U \& Gray JJ (1999). Molecular epidemiology of outbreaks of gastroenteritis associated with small round structured viruses in east Anglia, United Kingdom, during the 1996-1997 season. Journal of Clinical Microbiology, 37: 81-89.

13. Norcott JP, Green J, Lewis D, Estes MK, Barlow KL \& Brown DWG (1994). Genomic diversity of small round structured viruses in the United Kingdom. Journal of Medical Virology, 44: 280-286.

14. Hale A, Mattick K, Lewis D, Estes M, Jiang X, Green J, Eglin R \& Brown D (2000). Distinct epidemiological patterns of Norwalk-like virus infection. Journal of Medical Virology, 62: 99-103.

15. Wolfaardt $M$, Taylor MB, Grabow WOK, Cubitt WD \& Jiang $X$ (1995). Molecular characterisation of small round structured viruses associated with gastroenteritis in South Africa. Journal of Medical Virology, 47: 386-391.

16. Wolfaardt M, Taylor MB, Booysen HF, Engelbrecht L, Grabow WOK \& Jiang $X$ (1997). Incidence of human calicivirus and rotavirus infection in patients with gastroenteritis in South Africa. Journal of Medical Virology, 51: 290-296.

17. Parks CG, Moe CL, Rhodes D, Lima A, Barrett L, Tseng F, Baric R, Talal A \& Guerrant R (1999). Genomic diversity of "Norwalk-like viruses" (NLVs): pediatric infections in a Brazilian shantytown. Journal of Medical Virology, 58: 426-434.

18. Talal $A H$, Moe $C L$, Lima AA, Weigle KA, Barrett $L$, Bangdiwala SI, Estes MK \& Guerrant RL (2000). Seroprevalence and seroincidence of Norwalk-like virus infection among Brazilian infants and children. Journal of Medical Virology, 61: 117-124

19. Gabbay YB, Glass RI, Monroe SS, Carcamo C, Estes MK, Mascarenhas JD \& Linhares AC (1994). Prevalence of antibodies to Norwalk virus among Amerindians in isolated Amazonian communities. American Journal of Epidemiology, 139: 728-733. 
20. O'Ryan ML, Vial PA, Mamani N, Jiang X, Estes MK, Ferrecio C, Lakkis H \& Matson DO (1998). Seroprevalence of Norwalk virus and Mexico virus in Chilean individuals: assessment of independent risk factors for antibody acquisition. Clinical Infectious Diseases, 27: 789-795.

21. O'Ryan M, Salinas AM, Mamani N, Matson DO, Jiang X \& Vial $P$ (1999). Detection of Norwalk and Mexico viruses, two human caliciviruses in stools of Chilean children. Revista Medica de Chile, 127: 523-531.

22. Martinez N, Espul C, Cuello H, Zhong W, Jiang $X$, Matson DO \& Berke $T$ (2002). Sequence diversity of human caliciviruses recovered from children with diarrhea in Mendoza, Argentina, 1995-1998. Journal of Medical Virology, 67: 289-298.

23. Matsuno S, Sawada R, Kimura K, Suzuki H, Yamanishi S, Shinozaki K, Sugieda M \& Hasegawa A (1997). Sequence analysis of SRSV in fecal specimens from an epidemic of infantile gastroenteritis, October to December 1995, Japan. Journal of Medical Virology, 52: 377380 .

24. Nakata S, Honma S, Numata KK, Kogawa K, Ukae S, Morita Y, Adachi N \& Chiba S (2000). Members of the family Caliciviridae (Norwalk virus and Sapporo virus) are the most prevalent cause of gastroenteritis outbreaks among infants in Japan. Journal of Infectious Diseases, 181: 2029-2032.

25. Iritani N, Seto $Y$, Kubo H, Murakami T, Haruki K, Ayata M \& Ogura H (2003). Prevalence of Norwalk-like virus infections in cases of viral gastroenteritis among children in Osaka city, Japan. Journal of Clinical Microbiology, 41: 1756-1759.

26. Steele AD, Phillips J, Smit TK, Peenze I \& Jiang X (1997). Snow mountain-like virus identified in young children with winter vomiting disease in South Africa. Journal of Diarrhoeal Diseases Research, 15: 177-182.

27. Levett PN, Gu M, Luan B, Feardon M, Stubberfield J, Jamieson F \& Petric M (1996). Longitudinal study of molecular epidemiology of small round structured viruses in a pediatric population. Journal of Clinical Microbiology, 34: 1497-1501.
28. Farkas $T$, Jiang $X$, Guerrero $M L$, Zhong $W$, Wilton $N$, Berke $T$, Matson DO, Pickering LK \& Ruiz-Palacios G (2000). Prevalence and genetic diversity of human caliciviruses (HuCVs) in Mexican children. Journal of Medical Virology, 62: 217-223.

29. Jiang X, Matson DO, Velazquez FR, Calva JJ, Zhong WM, Hu J, Ruiz-Palacios GM \& Pickering LK (1995). Study of Norwalk-related viruses in Mexican children. Journal of Medical Virology, 47: 309316.

30. Roman E, Negredo A, Dalton RM, Wilhelmi I \& Sanchez-Fauquier A (2002). Molecular detection of human calicivirus among Spanish children with acute gastroenteritis. Journal of Clinical Microbiology, 40: 3857-3859.

31. Marie-Cardine A, Gourlain K, Mouterde O, Castignolles N, Hellot MF, Mallet E \& Buffet-Janvresse C (2002). Epidemiology of acute viral gastroenteritis in children hospitalized in Rouen, France. Clinical Infectious Diseases, 34: 1170-1178.

32. Oh DY, Gaedicke G \& Schreier E (2003). Viral agents of acute gastroenteritis in German children: Prevalence and molecular diversity. Journal of Medical Virology, 71: 82-93.

33. Pang XL, Honma S, Nakata S \& Vesikari T (2000). Human caliciviruses in acute gastroenteritis of young children in the community. Journal of Infectious Diseases, 181 (Suppl 2): S288-S294.

34. Pang XL, Joensuu J \& Vesikari T (1999). Human calicivirus-associated sporadic gastroenteritis in Finnish children less than two years of age followed prospectively during a rotavirus vaccine trial. Pediatric Infectious Disease Journal, 18: 420-426.

35. Boom R, Sol CJA, Salimans MMM, Jansen CL, Wertheim-van Dillen PME \& Van der Noordaa J (1990). Rapid and simple method for purification of nucleic acids. Journal of Clinical Microbiology, 28: 495-503.

36. Green J, Gallimore Cl, Norcott JP, Lewis D \& Brown DWG (1995). Broadly reactive reverse transcriptase polymerase chain reaction (RT-PCR) for the diagnosis of SRSV-associated gastroenteritis. Journal of Medical Virology, 47: 392-398. 